\title{
Complex Regional Pain Syndrome: Diagnostic and Treatment Conundrum
}

\author{
Srinivas Pyatia, ${ }^{\mathrm{a}}$, Miriam H. Feliu ${ }^{\mathrm{b}}$
}

\begin{abstract}
A 54-year-old man presented with a 12-week history of right lower extremity radicular pain with symptoms and signs of complex regional pain syndrome (CRPS). He reported a recent medical history of transient ischemic attack followed by cerebrovascular accident for which he underwent carotid endarterectomy. Following carotid endarterectomy, the patient was left with minimal residual speech and memory deficits, but concomitant presentation of right lower extremity radicular pain in the postoperative period was the reason for seeking pain relief. Right lumbar radiculopathy was suspected at the time of presentation to the pain clinic, and magnetic resonance imaging revealed bilateral moderate to severe lumbar foraminal stenosis, worse on the right side. Parasagittal lumbar epidural steroid injection, and aggressive multimodal pain management strategy was started resulting in significant improvement in pain scores, functionality and stress levels, albeit for a short period. Patient continued to obtain incomplete resolution of symptoms with conventional treatment. He underwent spinal cord stimulation at an early stage but only derived moderate benefit. The presented case is unusual because of overlapping etiologies that influenced our treatment plans. In this article, we will discuss the evidence for each of the questions raised by practitioners while treating aforementioned patient with CRPS.
\end{abstract}

Keywords: Complex regional pain syndrome; Cognitive behavioral therapy; Bisphosphonates; Spinal cord stimulation; Surgery

\section{Introduction}

Complex regional pain syndrome (CRPS) is a debilitating

Manuscript accepted for publication December 10, 2015

aDepartment of Anesthesiology, Duke University Medical Center and Anesthesiology Service, Durham Veterans Affairs Medical Center, Durham, NC 27710, USA

bDepartment of Psychiatry \& Behavioral Science, Duke University Medical Center, Director of Training, Chronic Pain Program \& Biofeedback Services, 4309 Medical Park Drive, Durham, NC 27704, USA

${ }^{\mathrm{c}}$ Corresponding Author: Srinivas Pyati, Department of Anesthesiology, Duke University Medical Center and Anesthesiology Service, Durham Veterans Affairs Medical Center, Durham, NC 27710, USA.

Email: Srinivas.pyati@duke.edu

doi: http://dx.doi.org/10.14740/jmc2378w chronic pain condition that can develop after tissue injury (surgical or traumatic) or spontaneously without a specific cause. CRPS can present as localized pain associated with features of neuropathic pain (burning, allodynia and hyperalgesia), and autonomic dysfunction (sudomotor and motor changes), but can also spread to regions distant from the original site of injury. The etiology of CRPS is not clear but in the pathophysiology both peripheral and central nervous systems are involved. In some cases, there is a predominance of the involvement of sympathetic nervous system. Several investigations to confirm diagnosis have been described but none are specific to CRPS. Currently there is no definitive treatment available and research has not supported the efficacy of commonly used interventions. Therefore, CRPS remains an under-recognized and under-treated medical entity because of its unpredictable presentation. Understanding the mechanisms involved in the development of CRPS is vital to tailor a mechanism-based multi-disciplinary treatment to prevent the far reaching consequences of CRPS such as excruciating pain and associated mental illnesses.

\section{Case Report}

A 53-year-old male patient presented to the pain clinic with approximately 12 weeks history of right lower extremity radicular pain followed by 3 weeks of symptoms of warmth, swelling and restricted right lower extremity movements. Past medical history was significant for recent transient ischemic attack followed by cerebrovascular event for which he underwent carotid endarterectomy and subsequent anticoagulation. In the ensuing week, patient developed sudden onset of right lower extremity radicular pain while driving.

On interview, he complained of severe pain (numerical rating scale score of 10/10) in the right lower extremity resulting in inability to bear weight on the affected limb, increased stress levels and impaired mood. Despite several weeks of multimodal analgesics and bed rest, his pain and disability continued to be severe. Physical examination revealed an obese male patient who arrived at the pain clinic in a wheel chair unable to ambulate for approximately 3 weeks. On inspection, his right leg was distinctly different from the left leg with marked redness and non-pitting edema (Fig. 1), which extended to the mid-calf level spreading from the lateral aspect of the foot. 


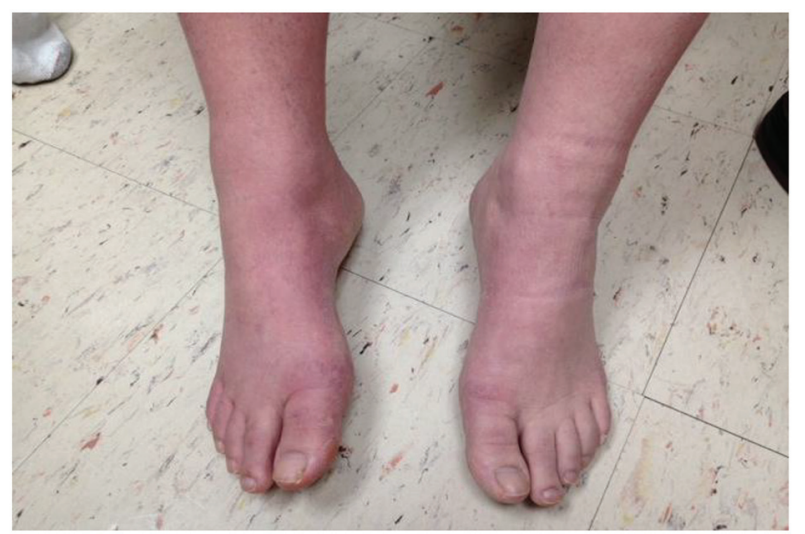

Figure 1. Edematous and hyperemic right lower extremity.

Physical exam was significant for hyperalgesia and allodynia on the lateral aspect of the right foot. We noted impaired dorsiflexion of the ankle, and in particular the right great toe dorsiflexion was severely impaired. Straight leg raise testing on the right was difficult to interpret due to severe pain. There were no visible signs of abnormality or impaired function in the contralateral extremity.

Magnetic resonance imaging performed at the time of radicular pain revealed severe right neural foraminal narrowing at L5-S1 level with equivocal neural compromise. Bone scan performed after initial consultation revealed a significant uptake of tracer in the distal tibia and bones of the foot, consistent with right L5-S1 dermatomal distribution (Fig. 2). Elec- tromyogram revealed a severely decreased amplitude and conduction velocity of right peroneal nerve consistent with chronic active right L5-S1 radiculopathy. Routine laboratory tests were essentially normal except elevation of blood glucose. A clinical diagnosis of the right L5 root irritation resulting in CRPS was made based on clinical history, physical exam and investigations. Patient was started on optimum doses of gabapentin and opioids followed by interlaminar lumbar epidural steroid injection performed under fluoroscopy that resulted in shortterm significant improvement in leg pain, movements and stress levels for up to a week. At this time, lumbar sympathetic block was performed with no clinical benefit.

\section{Discussion}

\section{Diagnostic conundrum}

Although Budapest criteria $[1,2]$ (Table 1) have significantly improved the accuracy of clinical diagnosis, CRPS continues to fascinate and perplex physicians for several reasons: it has an unpredictable presentation, largely unclear etiology and variable treatment responsiveness. In addition, the clinical presentation of CRPS is not always confined to the initial site of injury and frequently unrelated to the initial trauma. In our case, the initial presentation and signs suggested a clear diagnosis of CRPS; however, the etiology of CRPS remained unclear. Whether the outcome is determined by the etiology is a matter of discussion and ongoing research, but current evi-
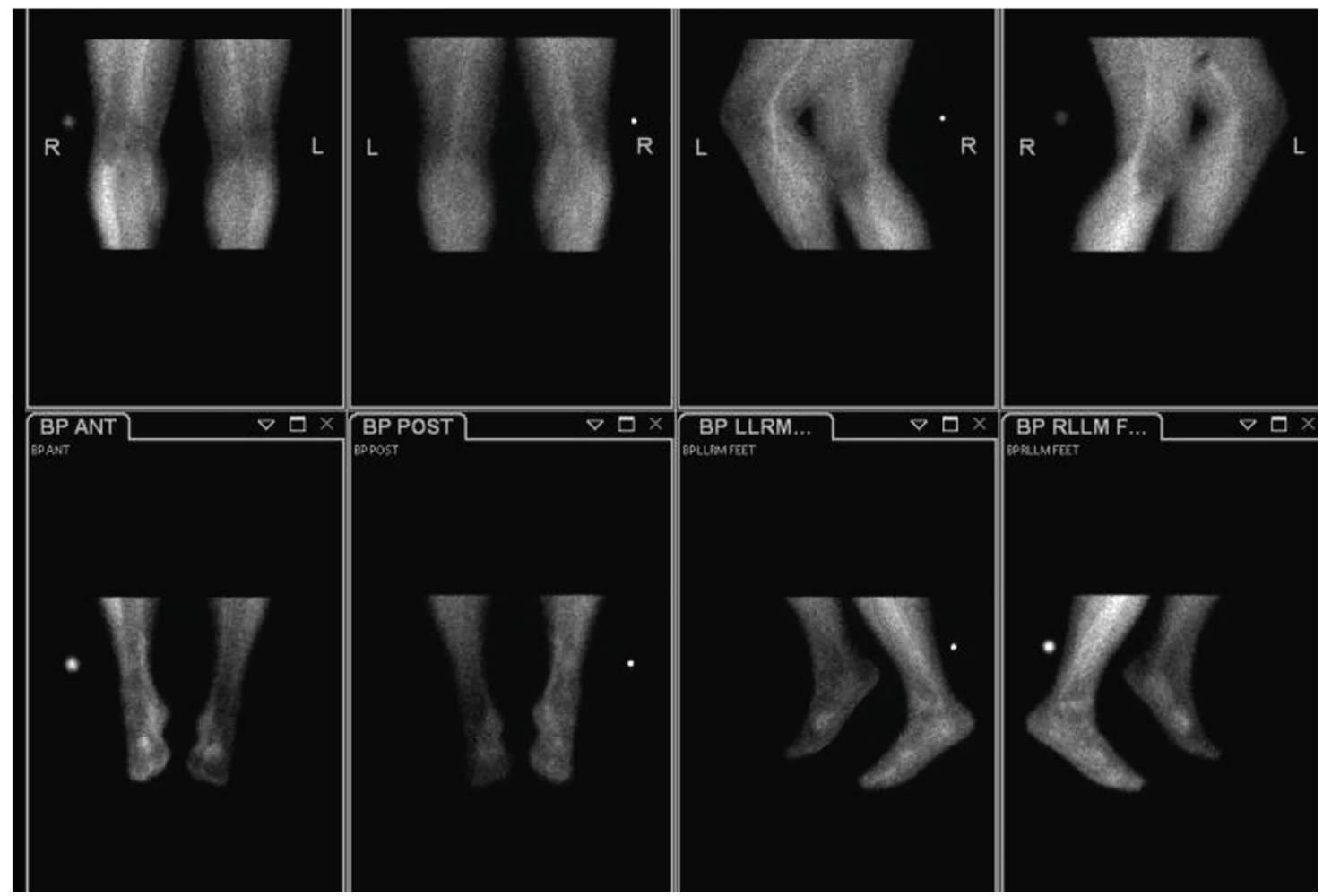

Figure 2. Bone scintigraphy showing increased tracer uptake in the right L5-S1 distribution. 
Table 1. Budapest Criteria 2010 [2]

1) Continuing pain, which is disproportionate to any inciting event

2) Must report one symptom in three of the following four categories;

Sensory: hyperesthesia and/or allodynia

Vasomotor: temperature asymmetry and/or changes in skin color

Sudomotor/edema: edema and/or sweating asymmetry or changes

Motor/trophic: decreased range of motion and/or motor dysfunction (weakness, tremor, dystonia) and/or trophic changes

3) Must display at least one sign out of the following two or more categories;

Sensory: evidence of hyperalgesia (to pinprick) or allodynia (to light touch) and/or joint movement

Vasomotor: evidence of temperature asymmetry and/or changes in skin color

Sudomotor: evidence of edema and/or sweating asymmetry or changes

Motor/trophic: evidence of decreased range of motion and/or motor dysfunction (weakness, tremor, dystonia) and/or trophic changes

4) There is no other condition that explains the signs and symptoms

dence points otherwise. For instance, based on MRI findings in our patient, one could assume that lumbar disc protrusion and resultant radiculitis of the L5 nerve root could explain the presentation. In conventional practice, the initial treatment is targeted at the disc protrusion and radiculitis to alleviate symptoms. However, this case raises some important diagnostic and therapeutic questions.

\section{Suspected radiculitis and CRPS}

Based on a few published case reports, evidence reveals that extraforaminal disc herniations and disc surgeries can lead to CRPS [3]. An elegantly presented case report by Weisz et al illustrates the association of cervical disc protrusion/surgical foraminotomy resulting in CRPS of the upper extremity in a 39-year-old man following injury to the neck [4]. The authors point out that the cause and effect was difficult to explain in this case and in such cases injury to nerves (e.g. sinuvertebral nerve) during the surgical procedure or by disc induced nerve compression appears to be the likely mechanism, but what remains elusive is why outcomes vary in different patients following routine spine surgeries or other non-surgical injuries.

In our case, the short-term alleviation of symptoms after epidural steroid injection suggested that radiculitis was the likely cause for radicular pain that most likely resulted in CRPS symptoms, supporting a view that surgical disc decompression or foraminotomy may offer pain relief and resolution of CRPS symptoms. However, neurosurgical evaluation revealed that surgery would aggravate CRPS symptoms and it was deemed inappropriate to pursue surgical option, a view in line with anecdotal evidence about the fear of aggravating disease process [5]. While most surgeons hold the view that surgery in patients with pre-existing CRPS can be devastating, the data supporting this view are scarce, and therefore require individual case risk-benefit analysis before considering "wait and watch" approach. A study by Dellon et al supports the view that surgery may be beneficial in certain patients. In 100 patients who had a diagnosis of "RSD", with both upper and lower extremity CRPS, authors observed excellent pain relief in approximately $50 \%$ of patients following surgical procedures such as neurolysis, joint denervation and neuroma excision [6]. The authors suggested that "continued input from injured joints or cutaneous afferents, and/or nerve compression" might result in CRPS-I, therefore suggesting that surgery may offer a better outcome than non-surgical treatments.

\section{Post-stroke CRPS}

CRPS is primarily a dysfunction of sensory and motor systems with frequent involvement of autonomic nervous system. A central lesion such as stroke can induce inflammatory changes in the periphery supported by the presence of high levels of calcitonin gene-related peptide (cGRP) causing neurogenic inflammation [7], and for this reason corticosteroids are sometimes used in CRPS with greater benefit. Similarly, the shoulder-hand syndrome following stroke has been frequently described in the literature suggesting that the underlying mechanisms for pain in CRPS are related to a combination of peripheral sensitization, neurogenic inflammation, autonomic dysfunction and dysfunctional descending adrenergic inhibition [8]. In addition, alteration in the organization of the primary somatosensory cortex and disinhibition of motor cortex has also been described in the pathophysiology of pain after stroke. Complete review of CRPS secondary to stroke is outside the scope of this discussion [9].

In our case, it is quite possible that a recent history of TIA/stroke precipitated CRPS. Our patient had evidence of left temporal, left parietal lobe and left basal ganglia infarcts resulting from a stroke couple of months prior to presentation of CRPS.

\section{Spontaneous onset CRPS}

It is possible that CRPS presentation of our case was coincidental. But, given the history of uncontrolled diabetes prior to clinical presentation and the evidence of moderate to severe polyneuropathy (motor $>$ sensory) in our patient it is reason- 
Table 2. Studies Evaluating Bisphosphonates in Complex Regional Pain Syndrome-I

\begin{tabular}{|c|c|c|c|c|c|c|}
\hline Study & Design & $\begin{array}{l}\text { Drug and } \\
\text { regimen }\end{array}$ & $\begin{array}{l}\text { Number (n) of } \\
\text { patients and } \\
\text { duration (D) } \\
\text { of follow-up }\end{array}$ & $\begin{array}{l}\text { Pain assessment } \\
\text { following } \\
\text { treatment }\end{array}$ & Outcomes & Comments \\
\hline $\begin{array}{l}\text { Varenna et } \\
\text { al, } 2013 \text { [12] }\end{array}$ & $\begin{array}{l}\text { Randomized, } \\
\text { double blind, } \\
\text { placebo- } \\
\text { controlled, } \\
\text { multicenter } \\
\text { trial }\end{array}$ & $\begin{array}{l}\text { Intravenous } \\
\text { neridronate-100 } \\
\text { mg (four times } \\
\text { over } 10 \text { days) }\end{array}$ & $\begin{array}{l}\mathrm{n}=82 \text { patients } \\
\mathrm{D}=1 \text { year }\end{array}$ & $\begin{array}{l}\text { Decrease in VAS } \\
\text { by } 46 \mathrm{~mm} \text { in } \\
\text { treatment group } \\
\text { vs. } 22 \mathrm{~mm} \text { in } \\
\text { placebo group }\end{array}$ & $\begin{array}{l}\text { 1) Better quality of } \\
\text { life in treatment group } \\
\text { 2) At } 1 \text { year all } \\
\text { patients were } \\
\text { asymptomatic }\end{array}$ & $\begin{array}{l}\text { 1) In early stage CRPS- } \\
1 \text { patients neridronate } \\
\text { provides long-term pain } \\
\text { relief and quality of life } \\
\text { 2) First study showing } \\
\text { conclusive evidence } \\
\text { of the efficacy }\end{array}$ \\
\hline $\begin{array}{l}\text { Robinson et } \\
\text { al, } 2004 \text { [22] }\end{array}$ & $\begin{array}{l}\text { Randomized, } \\
\text { double blind, } \\
\text { placebo- } \\
\text { controlled } \\
\text { study }\end{array}$ & $\begin{array}{l}\text { Single dose } \\
\text { intravenous } \\
\text { pamidronate } 60 \\
\text { mgs vs. saline }\end{array}$ & $\begin{array}{l}\mathrm{n}=27 \\
\mathrm{D}=3 \text { months }\end{array}$ & $\begin{array}{l}\text { VAS at } 3 \text { months } \\
\text { was lower in } \\
\text { treatment group } \\
(\mathrm{P}=0.043)\end{array}$ & $\begin{array}{l}\text { 1) Reduction in } \\
\text { patient's global } \\
\text { assessment of } \\
\text { disease severity in } \\
\text { the treatment group } \\
\text { 2) Higher SF-36 } \\
\text { score in treatment } \\
\text { group in function at } 3 \\
\text { months }(\mathrm{P}=0.047)\end{array}$ & $\begin{array}{l}\text { 1) Small study } \\
\text { and single dose } \\
\text { administration makes } \\
\text { generalizability of } \\
\text { efficacy harder } \\
\text { 2) Nevertheless, } \\
\text { this study highlights } \\
\text { the place for } \\
\text { bisphosphonates } \\
\text { in CRPS }\end{array}$ \\
\hline $\begin{array}{l}\text { Manicourt et } \\
\text { al, } 2004 \text { [23] }\end{array}$ & $\begin{array}{l}\text { 1) } \\
\text { Randomized, } \\
\text { double blind, } \\
\text { placebo- } \\
\text { controlled } \\
\text { study } \\
\text { 2) } \\
\text { Posttraumatic } \\
\text { CRPS-I } \\
\text { patients }\end{array}$ & $\begin{array}{l}\text { Oral } \\
\text { alendronate } 40 \\
\text { mg for } 8 \text { weeks }\end{array}$ & $\begin{array}{l}\mathrm{n}=40(20+20) \\
\mathrm{D}=24 \text { weeks }\end{array}$ & $\begin{array}{l}\text { 1) VAS: } \\
\text { significant } \\
\text { reduction }(\mathrm{P}< \\
0.001) \text { during } \\
\text { initial 12- } \\
\text { week period } \\
\text { 2) Mean VAS was } \\
33 \% \text { of placebo } \\
\text { group at } 12 \text { weeks }\end{array}$ & $\begin{array}{l}\text { 1) Improvement in } \\
\text { joint mobility, edema } \\
\text { of legs, tolerance } \\
\text { to pressure and } \\
\text { spontaneous pains } \\
\text { 2) Biomarker urinary } \\
\text { N-telopeptide } \\
\text { was measured }\end{array}$ & $\begin{array}{l}\text { 1) One patient dropped } \\
\text { out due to upper } \\
\text { GI intolerance } \\
\text { 2) Reduction in } \\
\text { urinary N-telopeptide } \\
\text { (NTX) was noted in } \\
\text { treatment group }\end{array}$ \\
\hline $\begin{array}{l}\text { Varenna et } \\
\text { al, } 2000 \text { [25] }\end{array}$ & $\begin{array}{l}\text { 1) } \\
\text { Randomized, } \\
\text { double blind, } \\
\text { placebo- } \\
\text { controlled } \\
\text { study } \\
\text { 2) Cross- } \\
\text { over trial }\end{array}$ & $\begin{array}{l}\text { 1) Intravenous } \\
\text { clodronate } 300 \\
\text { mg daily for } 10 \\
\text { days vs. placebo } \\
\text { 2) Placebo } \\
\text { group received } \\
\text { clodronate after } \\
\text { initial } 10 \text { days }\end{array}$ & $\begin{array}{l}\mathrm{n}=32 \\
\mathrm{D}=6 \text { months }\end{array}$ & $\begin{array}{l}\text { VAS }(0-100 \\
\text { mm }) \text { - treatment } \\
\text { group had overall } \\
\text { reduction in pain } \\
(93.6) \text { at } 6 \text { months }\end{array}$ & $\begin{array}{l}\text { 1) Clinical global } \\
\text { assessment }(0-3) \\
\text {-decreased }(\mathrm{P}=0.001) \\
\text { 2) Efficacy verbal } \\
\text { score }(0-3)-11 / 32 \\
\text { patients EVS }=1.6 \\
\text { 3) Urinary telopeptide } \\
\text { (marker of bone } \\
\text { resorption)-significant } \\
\text { decreases at } 40 \\
\text { days }(\mathrm{P}=0.0003)\end{array}$ & $\begin{array}{l}\text { 1) At } 6 \text { month, VAS } \\
\text { continued to improve } \\
\text { 2) No correlation } \\
\text { between VAS } \\
\text { and telopeptide } \\
\text { marker was seen } \\
\text { 3) Clodronate infusion } \\
\text { was well tolerated- } \\
\text { mechanism of action } \\
\text { seems to be different } \\
\text { when compared to } \\
\text { other bisphosphonates }\end{array}$ \\
\hline
\end{tabular}

$\mathrm{n}$ : number; D: duration; NRS: numeric rating scale; VAS: visual analogue scale. 
able to consider that diabetes induced microangiopathic processes may have contributed to CRPS presentation. Medical literature is riddled with case reports [10-12] describing cases of CRPS without obvious causes, but clinical evidence and animal experiments highlight that microvascular pathology and ischemia, in a subgroup of CRPS-I patients, can initiate disease processes that can present with abnormal pain sensations [13].

Spontaneous onset of CRPS, although highly debated, has been described in the literature. In a phenotypic characterization of patients with inciting cause (93\%) and in another group without a known etiology (7\%), de Rooij et al found that there were no major differences in clinical presentation between groups except that the onset of age in patients without an inciting cause was much earlier by 9 years [10]. The authors also concluded that the delay or unwillingness to make a diagnosis of CRPS in patients without a known precipitating cause could explain the "poorer prognosis" associated with spontaneous onset CRPS.

\section{Treatment options}

In the last couple of decades, the ambiguity about the nomenclature and diagnostic criteria for CRPS has evolved and undergone several changes allowing over or under-diagnosis of CRPS by many clinicians. There are no specific tests to diagnose CPRS with certainty, although thermography, quantitative sensory testing (QST), bone densitometry and response to sympathetic blocks have been used to aid clinical diagnosis. In most clinical situations looking for a cause for the onset of CRPS can be incredibly frustrating, and in majority of the cases one may not find the cause, but nevertheless a treatment that focuses on pain relief and prevention of functional deterioration is key. In this regard, a dedicated physical therapy team can profoundly impact quality of life and functionality of many patients. In the following paragraphs, we will review some of the important treatment considerations that are contentious and have not proven to be completely beneficial in all patients with CRPS.

\section{Ketamine infusion to alleviate CRPS symptoms}

With a renewed interest several investigators recently have used ketamine infusion in refractory CRPS patients with variable efficacy [14]. Ketamine is known to affect central sensitization via NMDA receptor antagonism, and thereby modulate nociceptive transmission but our systematic review on this topic revealed weak evidence in CRPS [15]. We noticed a large variation in ketamine infusion regimen, duration of infusion and duration of follow-up in our analysis. The one randomized trial, albeit with methodological flaws (small study, small effect size) included only 19 patients. This study was prematurely terminated because non-trial higher dose of ketamine provided better pain relief [16]. In the same year, Sigtermans' study [17] showed long-term pain relief up to 11 weeks but no functional assessment was performed in this study.
Recently, a commentary by Bell and Moore [18] elegantly demystifies the place for ketamine and its limited efficacy and application only in "certain clinical settings" of chronic pain conditions. Therefore, there is an urgent need for a welldesigned larger randomized controlled trial (RCT; n has been very small with most studies) to determine the exact role of ketamine infusion/coma in treating CRPS patients with a particular focus on duration of efficacy, its safety and related economic burden in a monitored setting. In the light of weak evidence, and in particular with the recent history of cerebrovascular accident, and memory and speech deficits, we did not consider ketamine therapy.

\section{Role of bisphosphonates in CRPS in the presence of abnormal bone scan}

Demineralization process and bone pain in CRPS is a poorly understood mechanism, although activated osteoclasts have been thought to play a role in pain transduction. An acidic environment produced by activated osteoclasts via acid sensing ion channels (ASICs) [19], and along with other potential mechanisms (capsaicin receptors, cGRP and nerve growth factor) may contribute to enhancing nociceptive transmission from the richly innervated periosteum. Intuitively, it appears that bisphosphonates by inhibiting osteoclastic activity may ameliorate pain transduction.

The fact that multiple mechanisms and receptors are involved in bone formation and resorption, it is simplistic to assume that bone pain in the presence of abnormal bone scintigraphy may be eliminated by bisphosphonates alone in CPRS-I patients. It is also worth noting that the role of bone scintigraphy in the diagnosis of CPRS is unclear (50\% sensitivity and $90 \%$ specificity) because of unclear pathophysiology of bone changes. Moreover, involvement of bone is only part of the complex pathophysiology involving loss or damaged $\mathrm{C}$ and $\mathrm{A}$ delta fibers resulting in central sensitization in CRPS [20, 21]. Nevertheless, some patients do present with "bone pain" that appears to be the reason why scintigraphy is still utilized as a diagnostic tool. Therefore, it appears that there is a subgroup of patients in early stage CPRS that may be responsive to bisphosphonates, and in such cases it is worthwhile considering oral or intravenous (IV) bisphosphonates and if necessary, collaboration with rheumatologists is desirable.

Bisphosphonates are used in myriad bone and metastatic conditions with good efficacy. Poor oral bioavailability and intolerable irritation to the esophagus and stomach leading to poor compliance have been the main drawbacks of bisphosphonates. In addition, IV administration requires prolonged infusions requiring admission to hospital and with considerable costs. However, the evidence for administration of these drugs is increasing and the attached table summarizes recent studies evaluating bisphosphonates in CRPS (Table 2 [12, 22-25]). Some of the important randomized trials are reviewed in the following paragraph.

In a double blind placebo-controlled study, the secondgeneration bisphosphonate pamidronate as a single IV dose (60 $\mathrm{mg}$ ) has been shown to provide significant pain relief 
Table 3. Studies Evaluating the Role of Spinal Cord Stimulation in Complex Regional Pain Syndrome

\begin{tabular}{|c|c|c|c|c|}
\hline Author & Study design & $\begin{array}{l}\text { Number of patients and } \\
\text { duration of follow-up }\end{array}$ & Pain score & Comments \\
\hline $\begin{array}{l}\text { Geurts et al, } \\
2013[26]\end{array}$ & $\begin{array}{l}\text { Prospective cohort } \\
\text { study on CRPS-I }\end{array}$ & $\begin{array}{l}\mathrm{n}=84 \\
\mathrm{D}=12 \text { years }\end{array}$ & $\begin{array}{l}30 \% \text { reduction in VAS } \\
\text { in } 40 \% \text { of patients }\end{array}$ & $\begin{array}{l}\text { Overall reduction in pain was less than } 50 \% \\
\text { At } 12 \text { years follow up } 60 \% \text { patients } \\
\text { continue to use the implant }\end{array}$ \\
\hline $\begin{array}{l}\text { Kemler et al, } \\
2008 \text { [27] }\end{array}$ & $\begin{array}{l}\text { Randomized controlled } \\
\text { trial-5 year follow-up }\end{array}$ & $\begin{array}{l}\mathrm{n}=36(\mathrm{SCS}+\mathrm{PT}) \\
18 \text { patients } \mathrm{PT} \text { only } \\
\mathrm{D}=2 \text { year } \\
* 24 \text { patients received } \\
\text { permanent implant }\end{array}$ & $\begin{array}{l}\mathrm{SCS}+\mathrm{PT} \text { was similar to PT } \\
\text { only in terms of pain relief }\end{array}$ & $\begin{array}{l}\text { 1) In subgroup analysis global } \\
\text { perceived effect and pain relief was } \\
\text { superior in patients who had SCS } \\
\text { 2) SCS efficacy decreases with time } \\
\text { but patient satisfaction remains high }\end{array}$ \\
\hline $\begin{array}{l}\text { van Eijis et } \\
\text { al, } 2012[28]\end{array}$ & Prospective & $\begin{array}{l}\mathrm{n}=6 \text { (out of } 74 \text { patients) } \\
\text { received early SCS } \\
\mathrm{D}=12 \text { months }\end{array}$ & $\begin{array}{l}35 \% \text { reduction in } \\
\text { mean pain relief }\end{array}$ & $\begin{array}{l}\text { Improvement in mental component of SF-36 } \\
\text { No functional improvement } \\
\text { was noted in any patient } \\
\text { SCS beneficial in early stage CRPS }\end{array}$ \\
\hline $\begin{array}{l}\text { Moriyama et } \\
\text { al, } 2012 \text { [29] }\end{array}$ & $\begin{array}{l}\text { Prospective, open label, } \\
\text { multicenter study }\end{array}$ & $\begin{array}{l}\mathrm{n}=14(\mathrm{CRPS}) \\
\mathrm{D}=6 \text { months }\end{array}$ & $\begin{array}{l}\text { Reduction in mean VAS ( } 79 \\
\text { to } 22 \mathrm{~mm} \text { ) and QOL from } \\
0.4 \text { to } 0.1 \text { at } 6 \text { months }\end{array}$ & $\begin{array}{l}\text { Although shorter follow results are } \\
\text { presented, significant reduction in pain } \\
\text { and improvement in QOL was noted }\end{array}$ \\
\hline $\begin{array}{l}\text { Kemler et al, } \\
2004[31]\end{array}$ & $\begin{array}{l}\text { Randomized controlled } \\
\text { trial-2 year follow up }\end{array}$ & $\begin{array}{l}\mathrm{n}=36(\mathrm{SCS}+\mathrm{PT}) \\
18 \text { patients } \mathrm{PT} \text { only } \\
\mathrm{D}=2 \text { year } \\
* 24 \text { patients received } \\
\text { permanent implant } \\
\mathrm{n}=18 \text { (PT only) }\end{array}$ & $\begin{array}{l}\text { Significant improvement in } \\
\text { SCS group }(P=0.001)\end{array}$ & $\begin{array}{l}\text { 1) Global perceived effect was superior } \\
\text { in SCS group ( } 43 \% \text { vs. } 6 \%) \\
\text { 2) Improvement in health } \\
\text { related QOL in SCS group } \\
\text { 3) No improvement in functional status } \\
\text { 4) High initial costs are offset by low } \\
\text { overall healthcare costs compared to } \\
\text { controls ( } \$ 60,000 \text { cheaper/patient) }\end{array}$ \\
\hline $\begin{array}{l}\text { Kumar et al, } \\
2011[32]\end{array}$ & $\begin{array}{l}\text { Retrospective review } \\
\text { of CRPS patients }\end{array}$ & $\begin{array}{l}\mathrm{n}=25 \\
\mathrm{D}=88 \text { months } \\
\text { Follow-ups at entry, } 3 \\
12 \text { and } 88 \text { months }\end{array}$ & $\begin{array}{l}\text { VAS: baseline } 8.4 \text {, at } 3 \text { months } \\
(4.8) \text { and at } 88 \text { months }(5.6)\end{array}$ & $\begin{array}{l}\text { Regression in effect but beneficial } \\
(\mathrm{P}<0.01) \text { at last follow-up } \\
\text { SCS is beneficial in early stage } \\
\text { of CRPS ( }<1 \text { year) } \\
\text { Reduction in analgesic consumption by } 25 \% \\
\text { Improvements noted in disability, } \\
\text { SF-36 and functional status }\end{array}$ \\
\hline $\begin{array}{l}\text { Bennett et al, } \\
1999[34]\end{array}$ & $\begin{array}{l}\text { Retrospective, } \\
\text { multicenter study on } \\
\text { CRPS-1 patients. } \\
\text { Two different systems } \\
\text { were implanted }\end{array}$ & $\begin{array}{l}\mathrm{n}=101 \\
\mathrm{D}=3 \text { years }\end{array}$ & $\begin{array}{l}\text { Significant reduction in pain } \\
(\mathrm{P}=0.0001) \text { in patients who } \\
\text { received dual octrode system }\end{array}$ & $\begin{array}{l}\text { High frequency stimulation and multi- } \\
\text { electrode stimulation is superior }\end{array}$ \\
\hline $\begin{array}{l}\text { Kumar et al, } \\
1997[35]\end{array}$ & Retrospective & $\begin{array}{l}\mathrm{n}=12 \\
\mathrm{D}=41 \text { months } \\
\text { Upper limb injury } \\
=5 \text { patients } \\
\text { Lower limb injuries } \\
=7 \text { patients }\end{array}$ & $\begin{array}{l}\text { VAS and McGill questionnaire } \\
\text { showed } 75 \%(n=8) \text { and } 50 \% \\
(n=4) \text { reduction in pain }\end{array}$ & $\begin{array}{l}\text { Early stage CRPS and younger patients } \\
\text { respond better with SCS implantation }\end{array}$ \\
\hline $\begin{array}{l}\text { Verdolin et } \\
\text { al, } 2007 \text { [36] }\end{array}$ & $\begin{array}{l}\text { Retrospective, } \\
\text { observational study } \\
\text { in veterans }\end{array}$ & $\begin{array}{l}\text { 1) } \mathrm{n}=10 \text { ( } 7 \mathrm{LE} \text { pain } \\
\text { and } 3 \text { UE pain) } \\
\text { 2) Symptom duration } \\
\text { was less than } 1 \text { year }\end{array}$ & $\begin{array}{l}\text { 1) Mean NRS } 1.6 \text { (pre- } \\
\text { SCS NRS 7.6) } \\
\text { 2) Reduction in morphine } \\
\text { equivalent consumption in } \\
\text { CRPS }(P=0.006) \text { patients }\end{array}$ & $\begin{array}{l}\text { 1) SCS improved PT efforts } \\
\text { 2) Early stage SCS is useful } \\
\text { in both CRPS-I and II } \\
\text { 3) Co-existing PTSD does } \\
\text { not affect SCS efficacy } \\
\text { 4) Long-term follow results needs to be seen }\end{array}$ \\
\hline
\end{tabular}

n: number; D: duration; NRS: numeric rating scale; VAS: visual analogue scale; PT: physical therapy; PTSD: post-traumatic stress disorder. 
and improvement in function at 3 months following infusion [22]. Similarly, Manicourt et al in a randomized study using oral alendronate (40 mgs daily for 8 weeks) vs. placebo also showed improvement in pain and mobility [23]. A recent randomized trial with IV neridronate (100 mg given 4 times during 10 day period) shows long lasting benefit (up to 1 year) in early stage CRPS-I patients [12]. It is encouraging to see a positive outcome with neridronate and as Varenna et al [12] suggested "where neridronate is not available" IV pamidronate $90 \mathrm{mg}$ (4 times during 10-day period) seems to be a reasonable alternative. However, it would be practical for patients and clinicians to have an oral bisphosphonate preparation with greater bioavailability and minimal adverse effects.

\section{Neuromodulation in CRPS to alleviate pain and to improve functional outcome}

Spinal cord stimulation (SCS) exerts its beneficial effect via various mechanisms, from its effect on wide dynamic range neurons in the spinal cord to supraspinal sites via its effect on both ascending nociceptive transmission and descending inhibitory pathways. For decades, SCS has been commonly used for failed back surgery syndrome and peripheral vascular diseases, but recently it has gained popularity as a therapeutic option during the early phase and in failed conservative management of CRPS (Table 3 [26-36]). In 2003, a descriptive analysis of 15 studies by Grabow et al showed only one RCT that reported positive effect with number needed to treat score of 3.0. It appears that definitive conclusions were not possible due to large variability in study designs, follow-up period and treatment effect. On the contrary, a recent prospective trial with long-term follow-up (12 years) showed over $60 \%$ of patients were still using SCS and in over $40 \%$ of patients significant pain reduction $(30 \%)$ was achieved on visual analogue scale (VAS). Over $60 \%$ of these patients had at least one surgical re-intervention during the follow-up period [26].

Our patient underwent a stimulator trial and obtained significant pain relief and patient opted to undergo a permanent spinal cord stimulator placement. Since implantation of permanent lead, he improved significantly in all areas of functionality, analgesia (30-40\%) and mood changes. He reported that he has continued to reduce opioid intake. What needs to be seen in such cases is the duration of efficacy of neuromodulation as "decay" in its effect is often seen in patients who have had stimulators for more than 5 years [27, 37]. Six months evaluation of stimulator effect revealed that our patient was dissatisfied with the analgesia and reported approximately $10 \%$ benefit from it. We believe that addition of cognitive behavioral therapy (CBT) will have an additive effect in obtaining maximal benefit of neuromodulation and other analgesic approaches in patients with suboptimal effect.

\section{Role of CBT in CRPS: a need for a change in clinical prac- tice}

CBT refers to a group of psychological techniques based on experimental behavior analysis and cognitive interventions that address the interaction between thoughts, feelings and behaviors. It addresses the system of belief, cognitive distortions and mood. There is significant evidence that shows its effectiveness in the treatment of multiple mental health disorders, including depression and anxiety [38]. A modern approach to pain management is based on the Biopsychosocial Paradigm and Bonica's Model of a multidisciplinary interaction [39]. It is recommended that $\mathrm{CBT}$ be utilized as an integral component in the treatment of chronic pain patients [40] resulting in increased coping and adjustment [41].

Similar to patients with many chronic pain conditions individuals with CRPS experience increased rates of psychiatric co-morbidities such as depression, anxiety and insomnia. The severe pain associated with CRPS often interferes with daily activities, social life and sleep. These symptoms may be exacerbated by catastrophizing, fear of movement and worsening of the condition. Therefore, incorporating a biopsychosocial model that addresses all the components of CRPS presentation is necessary, and this applies to all chronic pain disorders in general [42].

Since the early development of the spinal cord stimulator trials, the importance of patient selection has been recognized [43]. Such consensus has triggered a standard of practice in requiring a psychological evaluation, reinforced by the requisite for insurance coverage for spinal cord implantation. When patients are not candidates they can be treated with CBT in preparation for implantation. Even though there are no clinical trials showing the impact of CBT on SCS, the rationale behind including CBT in our case study and most CRPS patients lies on the association between psychophysiological aspects of mood, emotional regulation and distress levels on the clinical presentation [40, 44, 45].

An example of the development of a conversion disorder after a spinal cord implantation was described by Parisod et al [46]. Their patient developed a partial paralysis with no medical explanation, deemed as a conversion due to some emotional problems, he was treated with CBT and patient showed remission of his symptoms.

A recent study by McCraken et al [47] showed that patients who participated in a third wave CBT approach for 2 weeks showed significant improvements in coping with pain and followed the neuromodulation trial. Those participants who refused the trial through recommendation of their physician had worse symptoms of depression and acceptance of their pain condition. It seems that having CBT improves mood, pain and functioning as well as receptivity to proceed to alternatives such as SCS.

A study by Lee et al (2002) [48] showed significant improvement in children with a physical therapy protocol paired with CBT with significant improvement and long-term effects. More recently a pilot study incorporated mirror box therapy to CBT protocol to address body scheme in CRPS patients suggesting added benefits in mobility, body scheme and general rehabilitation [49].

Traditionally CBT has found an important place in treatment of psychiatric conditions, as they are strongly associated with chronic pain conditions. There is a plethora of significant amount of research including a CBT approach for chronic pain management. Table $4[48,50-53]$ includes some of the most 
Table 4. Studies Showing Effectiveness of Cognitive Behavior Therapy in Chronic Pain Conditions

\begin{tabular}{|c|c|c|c|}
\hline Authors & Techniques & Conditions & Results \\
\hline $\begin{array}{l}\text { Lee et al, } \\
2002[48]\end{array}$ & $\begin{array}{l}\text { CBT/ physical therapy } \\
\text { Children and adolescents }\end{array}$ & CRPS & $\begin{array}{l}89 \% \text { improvement in functional status } \\
\text { No need for assistive devices } \\
\text { No severe atrophy and contractures }\end{array}$ \\
\hline $\begin{array}{l}\text { Van Hoof et } \\
\text { al, } 2012[50]\end{array}$ & $\begin{array}{l}\text { Short intensive CBT } \\
\text { Pain management }\end{array}$ & Chronic low back pain & $\begin{array}{l}>65 \% \text { significant difference } \\
73 \% \text { reduction of health care use } \\
57 \% \text { reduction in analgesic consumption } \\
14 \% \text { decrease in opioid use }\end{array}$ \\
\hline $\begin{array}{l}\text { Monticone et } \\
\text { al, } 2014[51]\end{array}$ & $\begin{array}{l}\text { Multidisciplinary CBT } \\
\text { Disability/kinesiophobia }\end{array}$ & Chronic low back pain & $\begin{array}{l}61 \% \text { improvement in disability } \\
100 \% \text { returned to activities/work } \\
100 \% \text { discontinued medications }\end{array}$ \\
\hline $\begin{array}{l}\text { Knox et al, } \\
2014[52]\end{array}$ & $\begin{array}{l}\text { CBT - compliance } \\
\text { and effectiveness }\end{array}$ & Lumbar pain & $\begin{array}{l}\text { Increased compliance predicted greater } \\
\text { effect size and decrease in pain/disability }\end{array}$ \\
\hline $\begin{array}{l}\text { Heutink et al, } \\
2014[53]\end{array}$ & Multidisciplinary CBT & $\begin{array}{l}\text { Spinal cord injury/ } \\
\text { neuropathic pain }\end{array}$ & $\begin{array}{l}9-12 \text { months decrease in pain intensity and } \\
\text { pain related disability and anxiety levels } \\
\text { Increase in activity }\end{array}$ \\
\hline
\end{tabular}

important studies showing efficacy of its implementation in multiple chronic pain conditions.

\section{Summary}

In this article, we have attempted to describe a case of CRPS to analyze and review the complexities of diagnostic and treatments options. CRPS can be a frustrating disease to treat resulting in an unbearable suffering for some patients. In the pain clinic setting, it is uncommon to have patients with CRPS symptoms present early in the course of the disease.

The initial treatment of CRPS of lower extremity generally begins with a multimodal approach including non-opioid adjuvant medications, opioids, and interventional therapy consisting of lumbar sympathetic blockade. For now, formulating an evidence-based approach remains a problem due to lack of high quality evidence for the effectiveness of various interventions used for the treatment of CRPS. Until we have better evidence of the understanding of the pathophysiology of CRPS and the effectiveness of existing medications, a strategy that adopts a multidisciplinary approach that includes aggressive rehabilitation alongside CBT can make a profound impact on patient's quality of life. We concede that our case report does not add any new knowledge to existing data, but it raises several important questions as related to the presentation and management of a chronic pain problem that potentially requires a change in clinical practice. In any event, we feel that case reports such as ours serve multiple purposes; they add valuable knowledge to the existing literature pool, and encourage other physicians to strategize logical treatment and continue to report such cases to serve an important purpose of dissemination of clinical knowledge.

\section{Acknowledgement}

The authors would like to thank Dr Edwards and Dr Joel Gold- berg of Duke University School of Medicine and Durham Veterans Affairs Medical Center USA, for their valuable suggestions and opinions.

\section{Declaration of Interests}

SP and MF declare no commercial interests in any organizations.

\section{Funding}

No funding was received for preparation of this manuscript.

\section{Conflict of Interest}

None.

\section{References}

1. Harden RN, Bruehl S, Stanton-Hicks M, Wilson PR. Proposed new diagnostic criteria for complex regional pain syndrome. Pain Med. 2007;8(4):326-331.

2. Harden RN, Bruehl S, Perez RS, Birklein F, Marinus J, Maihofner C, Lubenow T, et al. Validation of proposed diagnostic criteria (the "Budapest Criteria") for Complex Regional Pain Syndrome. Pain. 2010;150(2):268-274.

3. Condon F, Kenny PJ, Griffin JG, O'Rourke K. Reflex sympathetic dystrophy associated with extraforaminal disc herniation at the L5-S1 level. J Spinal Disord. 1998;11(5):448-451.

4. Weisz GM, Houang M, Bogduk N. Complex regional pain syndrome associated with cervical disc protrusion and foraminotomy. Pain Med. 2010;11(9):1348-1351.

5. Ackerman WE, 3rd, Ahmad M. Recurrent postoperative 
CRPS I in patients with abnormal preoperative sympathetic function. J Hand Surg Am. 2008;33(2):217-222.

6. Dellon AL, Andonian E, Rosson GD. CRPS of the upper or lower extremity: surgical treatment outcomes. J Brachial Plex Peripher Nerve Inj. 2009;4:1.

7. Wasner G, Schattschneider J, Binder A, Baron R. Complex regional pain syndrome--diagnostic, mechanisms, CNS involvement and therapy. Spinal Cord. 2003;41(2):61-75.

8. Pertoldi S, Di Benedetto P. Shoulder-hand syndrome after stroke. A complex regional pain syndrome. Eura Medicophys. 2005;41(4):283-292.

9. Harrison RA, Field TS. Post stroke pain: identification, assessment, and therapy. Cerebrovasc Dis. 2015;39(34):190-201.

10. de Rooij AM, Perez RS, Huygen FJ, van Eijs F, van Kleef M, Bauer MC, van Hilten JJ, et al. Spontaneous onset of complex regional pain syndrome. Eur J Pain. 2010;14(5):510-513.

11. Tong HC, Nelson VS. Recurrent and migratory reflex sympathetic dystrophy in children. Pediatr Rehabil. 2000;4(2):87-89.

12. Varenna M, Adami S, Rossini M, Gatti D, Idolazzi L, Zucchi F, Malavolta N, et al. Treatment of complex regional pain syndrome type I with neridronate: a randomized, double-blind, placebo-controlled study. Rheumatology (Oxford). 2013;52(3):534-542.

13. Coderre TJ, Bennett GJ. A hypothesis for the cause of complex regional pain syndrome-type I (reflex sympathetic dystrophy): pain due to deep-tissue microvascular pathology. Pain Med. 2010;11(8):1224-1238.

14. Connolly SB, Prager JP, Harden RN. A systematic review of ketamine for complex regional pain syndrome. Pain Med. 2015;16(5):943-969.

15. Azari P, Lindsay DR, Briones D, Clarke C, Buchheit T, Pyati S. Efficacy and safety of ketamine in patients with complex regional pain syndrome: a systematic review. CNS Drugs. 2012;26(3):215-228.

16. Schwartzman RJ, Alexander GM, Grothusen JR, Paylor T, Reichenberger E, Perreault M. Outpatient intravenous ketamine for the treatment of complex regional pain syndrome: a double-blind placebo controlled study. Pain. 2009;147(1-3):107-115.

17. Sigtermans MJ, van Hilten JJ, Bauer MC, Arbous MS, Marinus J, Sarton EY, Dahan A. Ketamine produces effective and long-term pain relief in patients with Complex Regional Pain Syndrome Type 1. Pain. 2009;145(3):304311 .

18. Bell RF, Moore RA. Intravenous ketamine for CRPS: Making too much of too little? Pain. 2010;150(1):10-11.

19. Liu S, Cheng XY, Wang F, Liu CF. Acid-sensing ion channels: potential therapeutic targets for neurologic diseases. Transl Neurodegener. 2015;4:10.

20. Albrecht PJ, Hines S, Eisenberg E, Pud D, Finlay DR, Connolly MK, Pare M, et al. Pathologic alterations of cutaneous innervation and vasculature in affected limbs from patients with complex regional pain syndrome. Pain. 2006;120(3):244-266.

21. Oaklander AL, Rissmiller JG, Gelman LB, Zheng L, Chang Y, Gott R. Evidence of focal small-fiber axonal de- generation in complex regional pain syndrome-I (reflex sympathetic dystrophy). Pain. 2006;120(3):235-243.

22. Robinson JN, Sandom J, Chapman PT. Efficacy of pamidronate in complex regional pain syndrome type I. Pain Med. 2004;5(3):276-280.

23. Manicourt DH, Brasseur JP, Boutsen Y, Depreseux G, Devogelaer JP. Role of alendronate in therapy for posttraumatic complex regional pain syndrome type I of the lower extremity. Arthritis Rheum. 2004;50(11):36903697.

24. Adami S, Fossaluzza V, Gatti D, Fracassi E, Braga V. Bisphosphonate therapy of reflex sympathetic dystrophy syndrome. Ann Rheum Dis. 1997;56(3):201-204.

25. Varenna M, Zucchi F, Ghiringhelli D, Binelli L, Bevilacqua M, Bettica P, Sinigaglia L. Intravenous clodronate in the treatment of reflex sympathetic dystrophy syndrome. A randomized, double blind, placebo controlled study. J Rheumatol. 2000;27(6):1477-1483.

26. Geurts JW, Smits H, Kemler MA, Brunner F, Kessels AG, van Kleef M. Spinal cord stimulation for complex regional pain syndrome type I: a prospective cohort study with long-term follow-up. Neuromodulation. 2013;16(6):523529; discussion 529.

27. Kemler MA, de Vet HC, Barendse GA, van den Wildenberg FA, van Kleef M. Effect of spinal cord stimulation for chronic complex regional pain syndrome Type I: five-year final follow-up of patients in a randomized controlled trial. J Neurosurg. 2008;108(2):292-298.

28. van Eijs F, Geurts JW, Van Zundert J, Faber CG, Kessels AG, Joosten EA, van Kleef M. Spinal cord stimulation in complex regional pain syndrome type I of less than 12-month duration. Neuromodulation. 2012;15(2):144150; discussion 150 .

29. Moriyama K, Murakawa K, Uno T, Oseto K, Kawanishi M, Saito Y, Taira T, et al. A prospective, open-label, multicenter study to assess the efficacy of spinal cord stimulation and identify patients who would benefit. Neuromodulation. 2012;15(1):7-11; discussion 12.

30. Sears NC, Machado AG, Nagel SJ, Deogaonkar M, Stanton-Hicks M, Rezai AR, Henderson JM. Long-term outcomes of spinal cord stimulation with paddle leads in the treatment of complex regional pain syndrome and failed back surgery syndrome. Neuromodulation. 2011;14(4):312-318; discussion 318.

31. Kemler MA, De Vet HC, Barendse GA, Van Den Wildenberg FA, Van Kleef M. The effect of spinal cord stimulation in patients with chronic reflex sympathetic dystrophy: two years' follow-up of the randomized controlled trial. Ann Neurol. 2004;55(1):13-18.

32. Kumar K, Rizvi S, Bnurs SB. Spinal cord stimulation is effective in management of complex regional pain syndrome I: fact or fiction. Neurosurgery. 2011;69(3):566578; discussion 5578-5580.

33. Reig E, Abejon D. Spinal cord stimulation: a 20-year retrospective analysis in 260 patients. Neuromodulation. 2009;12(3):232-239.

34. Bennett DS, Alo KM, Oakley J, Feler CA. Spinal Cord Stimulation for Complex Regional Pain Syndrome I [RSD]: a Retrospective Multicenter Experience from 
1995 to 1998 of 101 Patients. Neuromodulation. 1999;2(3):202-210.

35. Kumar K, Nath RK, Toth C. Spinal cord stimulation is effective in the management of reflex sympathetic dystrophy. Neurosurgery. 1997;40(3):503-508; discussion 508509.

36. Verdolin MH, Stedje-Larsen ET, Hickey AH. Ten consecutive cases of complex regional pain syndrome of less than 12 months duration in active duty United States military personnel treated with spinal cord stimulation. Anesth Analg. 2007;104(6):1557-1560, table of contents.

37. Kemler MA, de Vet HC, Barendse GA, van den Wildenberg FA, van Kleef M. Spinal cord stimulation for chronic reflex sympathetic dystrophy--five-year follow-up. N Engl J Med. 2006;354(22):2394-2396.

38. Zhu Z, Zhang L, Jiang J, Li W, Cao X, Zhou Z, Zhang $\mathrm{T}$, et al. Comparison of psychological placebo and waiting list control conditions in the assessment of cognitive behavioral therapy for the treatment of generalized anxiety disorder: a meta-analysis. Shanghai Arch Psychiatry. 2014;26(6):319-331.

39. Flor H, Fydrich T, Turk DC. Efficacy of multidisciplinary pain treatment centers: a meta-analytic review. Pain. 1992;49(2):221-230.

40. Bruehl S. Complex regional pain syndrome: outcomes and subtypes. Clin J Pain. 2009;25(7):598-599.

41. Haythornthwaite JA, Benrud-Larson LM. Psychological assessment and treatment of patients with neuropathic pain. Curr Pain Headache Rep. 2001;5(2):124-129.

42. Feliu MH, Edwards CL. Psychologic factors in the development of complex regional pain syndrome: history, myth, and evidence. Clin J Pain. 2010;26(3):258-263.

43. Shealy CN, Taslitz N, Mortimer JT, Becker DP. Electrical inhibition of pain: experimental evaluation. Anesth Analg. 1967;46(3):299-305.

44. Harden RN, Oaklander AL, Burton AW, Perez RS, Richardson K, Swan M, Barthel J, et al. Complex regional pain syndrome: practical diagnostic and treatment guidelines, 4th edition. Pain Med. 2013;14(2):180-229.

45. Harden RN, Duc TA, Williams TR, Coley D, Cate JC,
Gracely RH. Norepinephrine and epinephrine levels in affected versus unaffected limbs in sympathetically maintained pain. Clin J Pain. 1994;10(4):324-330.

46. Parisod E, Murray RF, Cousins MJ. Conversion disorder after implant of a spinal cord stimulator in a patient with a complex regional pain syndrome. Anesth Analg. 2003;96(1):201-206, table of contents.

47. McCracken LM, Davies M, Scott W, Paroli M, Harris S, Sanderson K. Can a psychologically based treatment help people to live with chronic pain when they are seeking a procedure to reduce it? Pain Med. 2015;16(3):451-459.

48. Lee BH, Scharff L, Sethna NF, McCarthy CF, ScottSutherland J, Shea AM, Sullivan P, et al. Physical therapy and cognitive-behavioral treatment for complex regional pain syndromes. J Pediatr. 2002;141(1):135-140.

49. Vladimir Tichelaar YI, Geertzen JH, Keizer D, Paul van Wilgen C. Mirror box therapy added to cognitive behavioural therapy in three chronic complex regional pain syndrome type I patients: a pilot study. Int J Rehabil Res. 2007;30(2):181-188.

50. van Hooff ML, Ter Avest W, Horsting PP, O'Dowd J, de Kleuver M, van Lankveld W, van Limbeek J. A short, intensive cognitive behavioral pain management program reduces health-care use in patients with chronic low back pain: two-year follow-up results of a prospective cohort. Eur Spine J. 2012;21(7):1257-1264.

51. Monticone M, Ambrosini E, Laurini A, Rocca B, Foti C. In-patient multidisciplinary rehabilitation for Parkinson's disease: A randomized controlled trial. Mov Disord. 2015;30(8):1050-1058.

52. Knox CR, Lall R, Hansen Z, Lamb SE. Treatment compliance and effectiveness of a cognitive behavioural intervention for low back pain: a complier average causal effect approach to the BeST data set. BMC Musculoskelet Disord. 2014;15:17.

53. Heutink M, Post MW, Luthart P, Schuitemaker M, Slangen S, Sweers J, Vlemmix L, et al. Long-term outcomes of a multidisciplinary cognitive behavioural programme for coping with chronic neuropathic spinal cord injury pain. J Rehabil Med. 2014;46(6):540-545. 